\title{
"One country, two histories": how PRC and western narratives of Chinese modernity diverge
}

\author{
Niv Horesh ${ }^{1}$
}

\begin{abstract}
Held in October 2017, the 19th Chinese Communist Party (CCP) Congress enshrined not just $\mathrm{Xi}$ Jinping's grip on power. It also re-coated its ideology with a medley of Socialist and traditionalist buzz words that had been marginalized in the 1980s. During the height of the reform era, these increasingly made way for ideas borrowed from market economies. Predictably enough, the ideological ferment surrounding the 19th Party Congress has since also played out in the realm of education. This article examines in detail the most current history textbooks used in PRC classrooms to construe China's recent past. To that end, included in my exploration will not just be changing PRC attitudes to Chinese modern history, but also PRC instruction of world history. In passing, I will also compare the school material with the latest authoritative Western scholarly studies of the same topics by way of eliciting how PRC official historical narratives of 19th-2oth century events diverge from Western ones. A better understanding of those narratives is crucial to predicting how the PRC will behave on the world stage as an emerging global superpower.
\end{abstract}

Keywords: Chinese history, education, school textbooks, history teaching

Held in October 2017, the 19th Chinese Communist Party (CCP) Congress enshrined not just Xi Jinping's grip on power. It also re-coated its ideology with a medley of Socialist and traditionalist truisms that had been marginalized in the 1980s. During the height of the reform era, these increasingly made way - or so it seemed at the time - for ideas borrowed from market economies. A PRC researcher subsequently commended the new trend, noting in an article for the People's Daily, the Party's mouthpiece:2

After the Cold War, the influence of socialism has dimmed around the world, and the Western world even considers socialism a failure and its history has come to an end. But due to the success of socialism with Chinese characteristics, socialism has been revived in China.

On their part, foreign observers are quick to point out that Xi Jinping's enthusiasm for socialism, as professed in his published report to the 19th CCP Congress, is rooted in fact in a "Confucian world view", which goes against the historical grain of the dominant neoliberal discourse in the West. It is arguably serving, at present, as an anti-dote to the rise of nativist populism worldwide. ${ }^{3}$ Nevertheless, critics of the CCP suggest Xi's embrace of socialism is not so much an antidote to populism or neoliberalism but an offshoot of his own authoritarian tendencies. These tendencies, it is argued, are also leading Xi to seek historical rehabilitation for the calamities of the Mao Zedong era. ${ }^{4}$

Predictably enough, the ideological ferment surrounding the 19th Party Congress has also played out in the realm of education. For example, observers noted that a revised edition of one Chinese middle-school history textbook trialled in 2018 softened up its coverage of the disastrous Cultural Revolution, which Mao had unleashed in 1966. That softer coverage had not been announced in advance, but it seems to have since been rolled back. ${ }^{5}$ 
Vol. 7, No. 1, 114-125.

This latest episode of (attempted) textbook tweaking follows many previous aboutfaces that have punctuated Chinese history school teaching since the turn of the 2oth century. ${ }^{6}$ Under KMT rule (1927-1949), for example, primary school history teaching saw the uptake of anti-Western and anti-Japanese content. For, as is well known, the KMT advanced nationalism and irredentism particularly in the 1930s. In addition, the KMT narrative stressed Han superiority that allowed the "Chinese race" (中华民族) to assimilate over time both its neighbors and barbarian invaders. ${ }^{7}$

The USSR actively supported the establishment of the PRC in the 1950s, resulting at the school level in another permutation. Now, a Eurocentric streak of Marxism was promoted epistemologically, along with a schematic 5-stage paradigm of human evolution: from primitive society, through slavery, feudalism, and capitalism through to socialism. ${ }^{8}$ The mono-ethnic zeal of the Republican era was otherwise replaced with an emphasis on multi-ethnic harmony that complemented the South-South solidarity of the Bandung conference in 1955. Pro-Soviet feelings were, in turn, reflected in the castigation of Napoleon as a villain for his invasion of Russia over a century earlier. ${ }^{9}$ Concomitantly, the number of hours devoted to world history in the classroom were now matched with the time devoted to Chinese history instruction, and world history as a subject was brought forward so as to provide context for Chinese history lessons. ${ }^{10}$

Another history school textbook permutation occurred after Beijing had split from Moscow in 1961. The famous Sino-Soviet schism now vindicated in school textbooks the very same Napoleon as an exceptional figure in the mould of the despotic First Emperor of Qin (BCE c. 259-210), or even Mao himself."

China's geo-strategic insularity in the 1960s meant the famous Ming-era seafarer Zheng He (c. 1371-1433) was lionized in order to highlight Chinese technological precocity well before the advent of modern Western science. Equally importantly, peasant rebellions became the touchstone of historical epistemology, as opposed to the earlier Soviet emphasis on the urban proletariat as standard-bearer of communism. The overall tone was once again boldly nationalistic, much like in KMT textbooks of the $1930 .^{12}$

Deng Xiaoping came to power in 1978 and engendered a re-appraisal of the Mao era. However, key changes to history teachings occurred only much later in 1986. At that point, historical materialism in its Marxist iteration had been swept aside and communism was increasingly marginalized. Instead of class divisions, multi-ethnic patriotism was stressed. Most notably, the détente with Taiwan in the early 1980 s allowed for a more positive portrayal of the KMT's contribution to the war effort against Japan (1937-1945).13

At this point was the CCP return to collective leadership and a "low profile" internationally. This induced a gradual scaling back of the significance of peasant rebellions. Concomitantly, there was an effort to embed China into world history more cohesively and play down any ethnic tensions along the way. The key was suggesting Chinese premodern inventions and inter-civilizational contact all made for an integral part of world history and scientific progress. ${ }^{14}$

Arguably, the only diversion from the trend was in the immediate aftermath of the 1989 Tiananmen massacre, when an urgent need arose to replace the Maoist victorious narrative with one where China was a victim of foreign invasions. The purpose of that diversion was abetting patriotism on the back of "100 years of National Humiliation". ${ }^{5}$ Policymakers aimed to thereby deflect attention onto perceived foreign aggression and away from the burning domestic issues that the students had protested against in Tiananmen. Thus, for example, the famous generals Zuo Zuotang and Zeng Guofan of the Late Qing era were, from 1989 onward, no longer depicted in Maoist terms as villains who had suppressed the Taiping peasant rebellion (1850-1864), but rather as national heroes who helped repel Russian and Western invasions. ${ }^{16}$ 
Although foreign observers often see Xi as returning to Maoist authoritarianism and autarkism, he has cast himself in Davos as a sage leader of globalization. ${ }^{17}$ Therefore, a textbook relapse into full-blown Cultural Revolution lionization seems, for now, a step too far, even if term limits were removed from the post of CCP Chairman following the 19th Congress. Rather, as Gilbert Rozman suggests, the Chinese narrative is likely to remain focused on stability and peacefulness so as to contrast with perceived US disruption of the international system. ${ }^{18}$ In other words, the current textbooks are made to project China as a benevolent and status-quo power, pitted against the war-mongering West.

The aim of this article is to take stock of received historical narratives of modernity in the PRC in light of the developments described above. To that end, I will survey the most important history textbooks used in classrooms across the country. Included in my exploration will not just be PRC attitudes to the Chinese past, but also PRC instruction of modern world history. I will then compare the school material with influential Western studies of the same topics by way of eliciting how PRC official narratives about China critically diverge from key Western accounts. Herein, I do not purport to discuss how Western scholarly views of China evolved over the past decades, but merely to indicate which latest authoritative studies contrast with the "facts" presented in the textbooks. ${ }^{19}$

The two PRC history textbooks in the series at issue, covering as they do the dawn of modernity and the annals of the PRC, are accompanied by a world history textbook for ninth graders. ${ }^{20}$ The latter helps, in turn, to bring into relief the fault lines between Western and PRC understandings of the Chinese recent past. This is because the current version expressly attempts to link Chinese history with world history, whereas through much of the 196os and $70 \mathrm{~s}$ the thrust had been toward formulating Chinese history as sui generis. ${ }^{21}$

The scope of this article does not permit thorough discussion of all the historical events featuring in the textbooks. Instead, I will home in only on those events over whose interpretation there is a deep divide between Western and PRC historians. Such factors are not limited to schooling. Implicit here is the notion that historical consciousness formed at middle-school age will articulate into elite perceptions of the surrounding world later in life, thus affecting Chinese foreign policy. ${ }^{22}$

\section{The recent past}

The First Opium War (1839-42) serves as a convenient rupture framing the approach of both Western and PRC historians to Chinese modernity. The coverage of that war in either case is similar as both sides stress China's inability to forestall British naval power with traditional military thinking. ${ }^{23}$ Where the PRC rendition of the wars stands out here is in stressing the impact of Russian encroachment on Chinese territory immediately following the Opium Wars. That is to say, in the Chinese narrative - as conveyed in the textbook in question - the most pernicious upshot of the Opium War was not necessarily the opening of the Treaty Ports along China's coast. Rather, students can easily get the impression that the key detriment to China was the loss of 1.5 million sq. $\mathrm{km}$ of land to Russia. The territories lost as a result of the 1858 Aigun Treaty, the 1860 Peking Treaty and the 1881 Revised Peking Treaty were situated east and south of Lake Balkhash in modern Kazakhstan, and northeast of the Amur River. ${ }^{24}$

What explains the difference here is perhaps the unspoken notion that the Treaty Ports - despite the privileges they accorded to foreigners - were in essence a precursor of the modern Special Economic Zones opened to Westerners in the $1980{ }^{25}$ As was evident in the previous textbook volume, Qing territorial losses are seen by the authors as much more grave because they affected PRC sovereign territory at present. Against the backdrop of tense Sino-Russian relation until the late 1980s, Russia certainly comes across as much more of a frontier challenger, whereas Western scholarship tends to stress the maritime-frontier challenge that the West posed to China following the Opium Wars. ${ }^{26}$ 
Vol. 7, No. 1, 114-125.

The lost territory is central in historical terms to the modern project of re-establishing China's prestige among the nations of the world. Nevertheless, as Bartlett explains, that project obscures the fact that over two centuries of Qing rule prior to the Opium Wars, Chinese sovereign territory had in fact doubled in size as a result of military campaigns in the western frontier. ${ }^{27}$ In other words, notwithstanding territorial losses in the 19th century much of Western China became Chinese only fairly recently.

It would be interesting to observe whether such an alarmist narrative vis-à-vis Russia is maintained in future editions of the textbook, as Sino-Russian ties continue to improve. ${ }^{28}$ For now, however, it seems that formally resolving the border dispute with Russia did not necessarily tamp down revanchist content pointing, for example, to Vladivostok as a lost Chinese domain. ${ }^{29}$

\section{Peasant rebellions: good or bad?}

The current textbook treatment of the Taiping rebellion (1850-1864) has been dialled down compared to 1970 s textbooks, when the rebels were hailed as class heroes.

To be sure, here too it is described as "the greatest peasant rebellion in Chinese history". However, the treatment of the Taipings is not clear-cut, incorporating allegations of excessive authoritarianism and corruption of their top brass..$^{30}$ Rather than a case of good or evil, there is ambivalence here that speaks to residual post-Mao aversion to chaos. Some earlier iterations of school textbooks from the 1990s, discussed by Claudia Schneider, had actually passed a harsher judgement on the Taipings, describing them as "violently burning and slaughtering". ${ }^{31}$

Similarly, the current textbook exudes half-hearted empathy for the Boxer Rebellion (1899-1901). It is added in same breath that the Boxers suffered from superstitious features (迷信的色彩), in what is perhaps a manifestation of current suspicion of "heterodox cults". By contrast, the Sun Yat-sen streak of nationalism is celebrated as rational, yet it is subtly criticized for its anti-Manchu or Han-centric proclivity. ${ }^{32}$

The negative tone adopted vis-à-vis the Boxer rebellion in school textbooks in the 1980 s and gos was part of a larger shift in attitudes, away from the strictures of Maoism. That is to say, during the early reform era there was a need to embrace openness and dispel isolationist xenophobia. Concomitantly, it was acknowledged that all Chinese - irrespective of their class background - could be patriotic. Thus, luminaries who were formerly castigated as "feudal" were rehabilitated right from Confucius himself to Qing general Zeng Guofan, who quelled the Taiping rebellion. ${ }^{33}$

More generally, in dealing with Chinese nationalism, a key difference between Western accounts and the textbook under review is that the latter is placing an emphasis on erstwhile KMT office bearers who, despite not being Communist, ultimately preferred the PRC to Taiwan. The most notable examples are of course Li Zongren (1890-1969) and Li Jishen (1885-1959), who took part in the war against Japan. ${ }^{34}$ Others, like Hu Shi's son chose to stay in Beijing rather than retreat to Taiwan with the KMT. In that regard, the dominant discourse in the West is perhaps colored by the current Taiwan-PRC dispute, over-scripting the "commonality" that PRC commentators like to stress. As more details emerge in the West about the "tragedy of liberation" - to cite Dikötter's provocative term - it is also worth recalling that the personal histories of Li Jishen and others attest to the popularity of the Communists in the early 1950 . 35

\section{Fighting the Japanese enemy: who gets the credit?}

When it comes to the Second Sino-Japanese War (1937-1945), the historical narrative gap between the PRC and the West seems to be partly closing. Whilst the textbook tenaciously 
maintains it was the CCP that led the war against the invading Japanese, ${ }^{36}$ it also features, at length, acts of bravery by the KMT. In essence, the textbook all but concedes that the hardestwon battle against the Japanese was in fact Tai'erzhuang, in which KMT but not CCP forces under Li Zongren participated. ${ }^{37}$ The CCP's greatest coup against the Japanese was the 1940 “Battle of the 100 Regiments" (百团之战), but this was a smaller scale engagement. In that respect, therefore, the textbook treatment here partly accords with Rana Mitter's new history of the War. ${ }^{38}$

The change in PRC attitudes toward the KMT role in the War can be traced back to the mid-1980s. Then, a combination of factors made it possible: the thawing of relations with Taiwan, the fizzling out of the Cold War incentives to appease Japan, and the declining heft of Marxism in the public domain. ${ }^{39}$ As a result, patriotism rather than socialism became the legitimating plank of the PRC, as even the once vilified KMT leader, Chiang Kai-shek, would now be partly rehabilitated..$^{\circ}$

Unlike the Mao era, there is greater willingness in the PRC nowadays to acknowledge KMT sacrifice, and even admit the low-key nature of the CCP's guerrilla warfare tactics. But, on the other hand, there is also subtle condemnation in the textbook under review of Chiang Kai-shek's "scorched earth" tactics: for example, the bombing of dams near Zhengzhou, which held up Japanese advance but left millions of Chinese downstream homeless. ${ }^{41}$

The educational emphasis during the Mao era had been on the CCP as a victor and on the KMT as ineffectual and corrupt. More recently, as Wang explained, the "victor narrative" was replaced by a "victimization narrative", where CCP-KMT cooperation is stressed and where Japanese and Western insults to Chinese sovereignty are heightened. Namely, following the 1989 Tiananmen Square crackdown, the CCP leaders realized that: ${ }^{42}$

... the very survival of the Party depended largely on whether they could change the younger generation's attitude toward both the Western powers and the Party itself. Neither was the heroic and victor narrative helpful in cultivating the young generation's hateful attitude toward [the KMT] which made them less appreciative of the Communist revolution.

In that sense, more anti-Western agitation in the textbook was the flipside of less anti-Chiang agitation. But there was also a clear Japanese angle to the story of changing textbook attitudes. As explained by Caroline Rose:43

. . . up to the 1970s, Japan's role in the 1937-1945 Sino-Japanese War received relatively little attention in Chinese history textbooks. This was a reflection of the dominant narrative ... during the Mao period that, rather than drawing attention to the Chinese people's suffering at the hands of the Japanese, focused instead on the steadfast communist struggle against [the KMT]. In the descriptions of the Anti-Japanese War of Resistance in middle-school history textbooks of the 1970 and early 1980 , relatively little space, proportionally speaking, was devoted to Japanese actions per se. Indeed, the Japanese invasion merely formed the backdrop against which the communists and nationalists engaged in a battle for supremacy.

However, it is important to recall that the War was not entirely absent from the Maoist construction of the past. To be sure, over the course of the Mao era (1949-1976) the War occupied secondary place in PRC historical narratives, and there had not been a dedicated memorial thereto in Beijing. At the same time, as Kirk Denton argues, the PRC media in the early 1950s published many articles about memorialization of the War. ${ }^{44}$

What is less forthcoming in the Chinese narrative is appreciation for the huge sacrifice American (as well British and Indian) forces made, and ultimately for the decision to bomb Hiroshima and Nagasaki, as leading to Japan's surrender. These are only mentioned in brief in the accompanying world history textbook. ${ }^{45}$ This narrative thread is replicated in current Hong Kong textbooks too: later editions of Chinese history textbooks there accord 
Vol. 7, No. 1, 114-125.

"less prominence" to Allied support of the Chinese war effort. That is to say, previous editions had explicitly mentioned American aid as contributing greatly to China's victory, but the passage then went out of print. ${ }^{46}$

Since Xi Jinping's coming to power in 2012, the "victim" historical narrative that informed public discourse may have begun to swing again toward a "victor" one. In some PRC museums, for example, the war effort against Japan has been recast in a more internationalist vein as part of the worldwide struggle against fascism. Pride is otherwise taken in China's strength and newly acquired global stature, and China's centrality to the Allied victory in World War II is stressed. ${ }^{47}$ However, this victor narrative is not yet evident in the textbooks under review here, and it remains to be seen in what ways the furthering of Xi's grip on power will change textbook tenor in the future.

\section{PRC annals}

Perhaps the most salient textbook feature in describing the establishment of the PRC is its sensitivity to minority and peasant attitudes. It is stressed, for example, that most Tibetans welcomed PLA forces in the early 1950 and only a minority of reactionary circles sought independence, but few details are adduced as to the nature of the opposition. ${ }^{48}$ Similarly, it is suggested that land reforms in China proper in the early 1950 s were just and popular without mentioning the many cases of landlord executions that attended the reallocation of land. ${ }^{49}$

By far the starkest difference between the Chinese historical narrative, as presented here, and the Western one, surrounds the origins of the Korean War (1950-1953)..$^{\circ}$ There is virtually no discussion in the textbook of Kim Il-Sung's preliminary invasion of South Korea. Instead, the war is portrayed as having broken out as a result of a "sudden" invasion of North Korea by the USA (美国悍然派兵侵略朝鲜). In addition, whereas Western sources stress the constraints President Truman had imposed on General McArthur insofar as attacking China proper, the textbook erroneously suggests that bombing of Chinese cities in the Northeast was a matter of course during the War, as well as complaining about US forces blocking the Taiwan Straits..$^{1}$

Over one million Chinese soldiers perished in the counterattack. Nevertheless, the Korean War remains high on the textbook political agenda, as opposed to China's later border wars with India (1962) and Vietnam (1979). The latter two conflicts receive, in fact, no mention at all in the textbook. This is arguably because the Korean War made for a beacon of South-North rivalry. The India and Vietnam cases are in that sense more of an embarrassment to the South-South solidarity professed in the same PRC historical narrative. The new authoritative scholarly Western account of the Sino-Indian war puts the blame for the conflagration more evenly at China's doorstep, whereas previously Nehru's forward-deployment policies had been thought to have triggered it..$^{22}$ Vietnam, whilst not free of blame for the conflagration in the standard Western account, had been a close PRC ally in the Mao era. ${ }^{33}$

The Korean War is the capstone of what the CCP is wont to portray as a story of longstanding American bullying of China, while Americans tend to stress the benign nature of their foreign policy in contrast to old-world European colonialism. As noted, for example, by John Pomfret: ${ }^{4}$

Communist histories have twisted the story of America's two-hundred-year-long association with China. In the early days of the relationship, the Chinese are told, the United States schemed to colonise China, acting no better than the imperialist powers of Old Europe or even Japan. They're taught that American charity was a trick. The Chinese version of World War II airbrushes American sacrifice from the tale. China, not the United States, beat Japan, the Chinese learn. As for the Korean War - to this day Chinese textbooks maintain that South Korea, backed by America, started the conflagration when in truth it was the North Koreans supported by Joseph Stalin and Mao. 
Nonetheless, America is not the primary evil-doer across the textbooks. As mentioned earlier, there is generally a more negative attitude toward Russia in all volumes. The only exception is when mentioning the 1957 building of the first bridge across the Yangzi, which was completed with Soviet aid. Elsewhere, there is scant mention of the aid, and even less detail about the rupture of relations with the Soviet Union in the early 19605.55

\section{Mao's chaos and recovery}

Notably, there is in this edition of the textbook a fairly stark condemnation of the Great Leap Forward (1958-1960) as a misguided campaign ignoring realities on the ground. ${ }^{6}$ Nevertheless, throughout, the authors have made palpable efforts not to discard the Mao legacy lock, stock and barrel. For example, there is still praise for the sacrifices individuals like Lei Feng and Jiao Yulu had made, as well as accolades for the scientific achievements of the 1960s, in particular the Deng Jiaxian-led nuclear project. Nowhere is there mention of the great famine that attended the Great Leap, or the death-toll resulting therefrom. ${ }^{57}$

More pertinently, it is clear that prior to the latest (attempted) revision, the textbook included condemnation of the Cultural Revolution (1966-1976) as a mistake personally committed by Mao, although there is admission that Deng Xiaoping had been, at first, his steward in this endeavor. Much regret is expressed at the same breath over the purges of the Party in the late 1960 s but, once again, there is no mention of any death toll arising from the Cultural Revolution, which is thought in the West to be over a million..$^{58}$

Mao's posthumous loyalists are subsequently condemned, but Hua Guofen, who succeeded Mao in 1976 is, curiously enough, not mentioned by name. Instead, the restoration of the constitution and legal system in the 1980s under Deng Xiaoping is stressed.59

The 1980 are thus favorably portrayed as years of return to law and order and of the opening of Special Economic Zones. However, the textbook erroneously states that Shanghai had opened to significant foreign investment as early as 1984 alongside Guangzhou, whereas in reality it was placed on the backburner until 1992 due to political sensitivities arising from this city's association with foreign influence in the $19305 .{ }^{60}$ Disturbingly, the Tiananmen crackdown of 1989, which forestalled Deng's economic opening up until 1992, is not mentioned by name. However, the unrest of the late 1980 os is hinted at in the world history textbook section dealing with the disintegration of the Soviet bloc.

Apart from the China-India border war (1962) and the China-Vietnam border war (1979), other key events that are deprived of mention in this edition are the 1995-6 missile crisis across the Taiwan Straits. Here, of course, the sensitivity is even more pronounced as the issue touches on a core PRC interest, and anything that might tarnish cross-strait "brotherly solidarity" can be expected to be expunged from official writings.

\section{World annals}

The attendant world history textbook requires a separate section because it is not chronologically ordered and, therefore, does not readily lend itself to cross-referencing with the Chinese history one. Presumably this was intentional, as the volume deals with recent world events of highly sensitive nature and relevance to CCP legitimacy, there was perhaps a need to obfuscate the discussion by diffusing tracts across time and place. Or else the separation may have had more to do with the curriculum “character" reforms (素质教育) of the early 20oos, and the idea (partly influenced by prevalent Anglo-American thinking on history education as a means of imparting generic "analytical skills") that a thematic rather than chronological treatment was more stimulating. ${ }^{61}$

Notably, the treatment of Stalin is downright negative here, perhaps because it allows more latitude for subtle criticism of Mao as compared with the perimeters of the 
Vol. 7, No. 1, 114-125.

Chinese history textbook. Thus, Stalin's personality cult and purges of the 1930 (there is no mention of gulags) are described as the embodiment of wrong doing (弊端的体现). He is accused of ruining the legal system of the Soviet Union, and of persecuting outstanding innocent Party cadres. ${ }^{62}$

If treatment of Stalin is fairly consonant with Western studies, the historical rupture re-emerges when dealing with the Nazi persecution of Jews. The holocaust death toll is laconically given as "several million", escaping specificity. Neither is there mention of the specificity of concentration and death camps, leaving students to imagine the genocide as common war afflictions similar to many others in history. ${ }^{63}$

Moreover, the holocaust is played down as simply a "massacre" (tusha) as opposed to the "great massacre" (da tusha), a term used in other translations. ${ }^{64}$ There is a conspicuous lack of explanation for the racial-purity motives behind the Nazi genocide. Neither is the linkage between the holocaust and the creation of the state of Israel discussed at all.

The disjointed nature of the content also comes across in efforts to explain the breakup of the Soviet Union. To be sure, many resources have been invested by the PRC leadership in understanding (and avoiding) the circumstances that led to the political demise of Gorbachev. As David Shambaugh explains, the Chinese knee-jerk reaction in the early 1990 os was to blame the West for conspiring to topple Gorbachev. However, more serious scholarly efforts were made later on to analyze the situation. The conclusions drawn, for the most part, were that Gorbachev aimed at political reforms too fast, but that ultimately the Soviet system had already been weakened by his time on account of economic malfunction and the cost of maintaining domination in various hot spots around the world. ${ }^{65}$

The world history textbook reflects these conclusions, particularly as regards to the perceived need to stagger political reform. Khrushchev, for example, is portrayed favorably for correcting Stalin's line. But it is suggested in the same breath that his wholesale condemnation of Stalin was wrong because it paved the way for systemic nihilism. On the other hand, Khrushchev is also deemed not to have gone far enough in terms of relaxing the USSR command economy. ${ }^{66}$

The discontent across the Soviet Bloc is conveyed through a lengthy tract on the 1956 Hungarian Revolt. But, strangely enough, it leaves readers to assume János Kádár de-Stalinized Hungary, whereas in fact it had been his predecessor, Imre Nagy, who had embarked on that course. By contrast, the Prague Spring of 1968 is only perfunctorily mentioned as having been suppressed (镇压) by the USSR. ${ }^{67}$

Arguably, the notion that the West conspired to divide the Soviet Bloc may also be felt in the textbook, notwithstanding the silence regarding the circumstances of the SinoSoviet schism. This comes across particularly in the tract about the break-up of Yugoslavia. For example, it is suggested that Slovenia and Croatia were encouraged in 1991 to declare independence by the West. There is also criticism here of the NATO bombing of Serbia, including the destruction of the Chinese embassy in Belgrade, but no mention at all of the horrors of Srebrenica. ${ }^{6}$

\section{Conclusions}

Although there is, in a few instances, a knee-jerk tendency to blame the West for China's 19th-2oth century woes, Russia looms larger in the textbooks under review both in terms of what is connoted (territorial encroachment) and what is left unmentioned (border clashes attending the Sino-Soviet split in the 1960s). Neither are the implications of China's realignment with the US following Nixon's visit to Beijing amply analyzed. In that sense, the current historical narrative seems to be trailing far behind the fast improvement in SinoRussian relations on the ground, and it would be interesting to see if this element persists later in the $\mathrm{Xi}$ era. Or, if left unchanged in textbooks, that narrative may indeed be 
underscoring the inherent tension pervading Sino-Russian relations behind the cordial rhetoric $\mathrm{Xi}$ and Putin both emit at present.

The KMT, on the other hand, comes in for rather favorable treatment arising from the struggle against Japanese occupation. Herein, an about-face in history textbook narratives obtains as compared with the Mao era, during which Japanese aggression was played down and the KMT vilified. This trend also broadly accords with new Western scholarly studies.

Claims of a Maoist turn under Xi Jinping notwithstanding, the Great Leap Forward and Cultural Revolution come in for fairly harsh criticism, sometimes also through the vehicle of anti-Stalin tracts, it would appear. However, as the CCP verdict on the collapse of the Soviet Union behooves, the textbook is careful not to tar the entire Mao era with the same brush, noting, in particular, achievements in the area of land reform, science and education. In that sense, Stalin per se receives much harsher treatment than Mao.

The glaring omissions of key international events may be baffling to Western readers. Chinese students are practically left without knowledge of not just the circumstances that led to the Sino-Soviet split, but also of events that might tarnish China's image as irenic promoter of South-South solidarity: the 1962 border war with India and the 1979 clash with Vietnam.

By far the starkest difference between the Chinese historical narrative, as presented here, and the Western one surrounds the origins of the Korean War (1950-1953). Curiously, the outbreak of the Korean War in 1950 is mentioned at great length. But unlike Western accounts that suggest Mao had abetted Kim Il-Song's adventurism, our textbook suggests China joined the war effort because of US bombing of its own soil, that is long after the outbreak of the war. Western accounts stress, by contrast, that Truman had carefully instructed McArthur not to prosecute the War into Chinese territories and fired McArthur in the end due to insubordination. There was, in the interim, some inadvertent bombing of border facilities but nothing like a systematic attack on China, even if China did warn the US of getting near the Yalu River.

Herein, this article does not purport to suggest Western history textbooks are completely devoid of historical "narratives" of their own, or that either side may be standing on the right side of history. Indeed, it laments the lack of attention in some Western accounts to defectors like Li Jishen as bearing out the popularity of the CCP in the 1950s. Rather, the article has focused on gaps in historical interpretations between the PRC and the West as underpinning different world views that may lead to world-governance clashes. At the same time, it also optimistically points to areas where the narrative gap is closing, the KMT record and the Great Leap Forward being two key cases in point.

\footnotetext{
Notes

${ }^{1}$ Associate Professor at Western Sydney University, Niv Horesh is the author of many books on China including How China's Rise is Changing the Middle East (Routledge, 2019), co-authored with Anoushiravan Ehteshami.

${ }^{2}$ http://en.people.cn/n3/2018/o222/c9oooo-9428658.html

3 https://www.straitstimes.com/opinion/the-confucian-roots-of-xi-jinpings-policies

${ }^{4}$ https://www.abc.net.au/news/2018-05-04/china-xi-jinping-is-pushing-a-marxist-revival/9724720

${ }^{5}$ https://www.scmp.com/news/china/society/article/2127817/controversy-over-chinese-textbooks-culturalrevolution-chapter

${ }^{6}$ Gotelind Müller, “Teaching 'The Others' History’ in Chinese Schools: The State, Cultural Asymmetries and Shifting Images of Europe", in Gotelind Müller ed. Designing History in East Asian Textbooks: Identity Politics and Transnational Aspirations (Routledge, 2011), pp. 32-59.
} 
Vol. 7, No. 1, 114-125.

${ }^{7}$ Alisa Jones, "Changing the Past to Serve the Present: History Education in Mainland China", in Edward Vickers ed. History Education and National identity in East Asia (Routledge, 2013), p. 69.

${ }^{8}$ Lawrence R. Sullivan. “The Controversy over 'Feudal Despotism': Politics and Historiography in China, 1978-82", in Jonathan Unger ed., Using the Past to Serve the Present: Historiography and Politics in Contemporary China (M.E. Sharpe, 1993), pp. 174-204.

${ }_{9}^{9}$ Gotelind Müller, op. cit.

${ }^{10}$ Alisa Jones, op. cit, p. 73

"Barbara Barnoin and Yu Changgen, Ten Years of Turbulence: The Cultural Revolution (Routledge, 2012), p. 28.

${ }^{12}$ Edward Vickers, "Defining the Boundaries of 'Chineseness': Tibet Mongolia, Taiwan, and Hong Kong in Mainland History Textbooks", in Stuart J. Foster and Keith A. Crawford eds., What Shall We Tell Our Children? International Perspectives on School History Textbooks (Greenwich Information Age, 2006), pp. 25-48.

${ }^{13}$ Alisa Jones, op. cit, p. 85; Caroline Rose, "Changing Views of the Anti-Japanese War in Chinese High School History Textbooks", in Paul Morris, Naoko Shimazu, and Edward Vickers. eds. Imagining Japan in Post-war East Asia: Identity Politics, Schooling and Popular Culture (Routledge, 2013), pp. 129-148; Edward Vickers and Yang Biao, "Shanghai's History Curriculum Reforms and Shifting Textbook Portrayals of Japan", China Perspectives 4(2013), pp. 29-37. See also Rana Mitter, "Behind the Scenes at the Museum: Nationalism, History and Memory in the Beijing War of Resistance Museum, 1987-1997", China Quarterly 161(2000), pp. 279-293.

${ }^{14}$ Gotelind Müller, op. cit.

${ }^{15}$ On the engendering of the "10o Years of National Humiliation" trope see e.g. William A. Callahan, China: The Pessoptimist Nation (Oxford University Press, 2012), Chapter 3.

${ }^{16}$ See e.g. Yingjie Guo and Baogang He, "Reimagining the Chinese Nation: the 'Zeng Guofan' Phenomenon”, Modern China 25.2(1999), pp. 142-17o. See also Peter H. Gries, China's New Nationalism: Pride, Politics, and Diplomacy (University of California Press, 2004), p. 70; Edward Vickers, "Museums and Nationalism in Contemporary China", Compare 37.3(2007), pp. 365-382; Zheng Wang, Never Forget National Humiliation: Historical Memory in Chinese Politics and Foreign Relations (Columbia University Press, 2014), p. 102.

${ }^{17}$ https://www.scmp.com/news/china/economy/article/2141099/chinese-president-xi-jinping-standsglobalisation-free-trade

${ }^{18}$ Gilbert Rozman, East Asian National Identities: Common Roots and Chinese Exceptionalism (Wilson Center, 2012), p. 77.

${ }^{19}$ For an overview of how the Western scholarly discussion of Chinese history evolved over time, see e.g. Paul Cohen, Discovering History in China: American Historical Writing on the Chinese Recent Past (Columbia University Press, 2010); Ming Dong Gu, Sinologism: An Alternative to Orientalism and Postcolonialism (Routledge, 2013); Harriet T. Zurndorfer, China Bibliography: A Research Guide to reference Works about China Past and Present (Brill, 1995), pp. 4-44.

${ }^{20}$ Zhongguo lishi [Chinese History, 4 vols., 7 th-8th Grades, Approved Textbooks for Trial by the Ministry of Education], Beijing: Renmin jiaoyu chubanshe, 2001-2017; Shijie lishi [World History, 2 vols., 9th Grade, Approved Textbooks for Trial by the Ministry of Education], Beijing: Renmin jiaoyu chubanshe, 2001-2017. ${ }^{21}$ Gideon Shelach-Lavi, "Our China' - Archaeological Museums as Reflections of National and Local Identities in China", Historia 37(2016), pp. 111-140.

${ }^{22}$ See e.g. Niv Horesh and Ruike Xu, "CCP Elite Perception of the US since the Early 199os: Wang Huning and Zheng Bijian as Test Cases", Asian Affairs 48.1(2017), pp. 51-74.

${ }_{23}$ Julia Lovell, The Opium War (Picador, 2011); Mao Haijian, Tianchao de bengkui (Sanlian, 1995).

${ }^{24}$ Zhonguo lishi 8.1, p. 11. See also Joseph W. Esherick, "From Tribute to Treaties to Popular Nationalism", in Brantly Womack ed., China's Rise in Historical Perspective (Rowman and Littlefield, 2010), pp. 19-38.

${ }^{25}$ See e.g. Rudolf G. Wagner, "The Role of the Foreign Community in the Chinese Public Sphere", China Quarterly 142(1995), pp. 423-443.

${ }^{26}$ See e.g. Jonathan D. Spence, The Search for Modern China (Norton, 1990). Cf. Paul Cohen, Discovering History in China: American Historical Writing on the Chinese Recent Past (Columbia University Press, 2010). Cf. R.K.I. Quested, Sino-Russian Relations: A Short History (Routledge, 2005).

${ }^{27}$ Thomas Bartlett, "The Role of History in China's View of the World Today", Pacifica Review 13.1(2001), pp. 117-126, p. 121.

${ }^{28}$ https://foreignpolicy.com/2019/10/o3/xi-jinping-has-embracecd-vladimir-putin-for-now/; see also Gilbaer Rozman, The Sino-Russian Challenge to the World Order (Stanford University Press, 2014). 
${ }^{29}$ For a wider-angle discussion see Neville Maxwell, "How the Sino-Russian Boundary Conflict was Finally Settled. From Nerchinsk 1689 to Vladivostok 2005 via Zhenbao Island 1969", Critical Asian Studies 39.2(2007), pp. 229-253.

$3^{30}$ Zhonguo lishi 8.1, p. 17 .

${ }^{31}$ Claudia Schneider, "Looking at our story with different eyes: History textbooks on both sides of the Taiwan Strait", InterrnationaleSchulbuchforschung 27.1(2005), p. 68-69.

${ }^{32}$ Zhonguo lishi 8.1, p. 33. See also Jun Qinwu, Mandarins and Heretics: The Construction of "Heresy" in Chinese State Discourse (Brill, 2016).

${ }_{33}$ Alisa Jones, op. cit., p. 82.

${ }^{34}$ Zhonguo lishi 8.1, pp. 96-98; see also Zhonguolishi 8.2, p. 2.

35 Frank Dikötter, The Tragedy of Liberation: A History of the Chinese Revolution 1945-1957 (Bloomsbury, 2015).

${ }^{36}$ Zhonguo lishi 8.1, pp. 106-107.

${ }^{37}$ Zhonguo lishi 8.1, pp. 96-98, p. 102

${ }^{38}$ Rana Mitter, China's War with Japan, 1937-1945: The Struggle for Survival (Penguin, 2013).

39 Rana Mitter, "China's 'Good War': Voices, Locations, and Generations in the Interpretation of the War of Resistance to Japan", in Sheila Miyoshi Jager and Rana Mitter eds., Ruptured Histories: War, Memory and the Post-Cold War in Asia (Harvard University Press, 2007), pp. 173-174.

${ }^{40}$ Edward Vickers, "Frontiers of Memory: Conflict, Imperialism, and Official Histories in the Formation of Post-Cold War Taiwan Identity", in Sheila Miyoshi Jager and Rana Mitter eds., Ruptured Histories: War, Memory and the Post-Cold War in Asia (Harvard University Press, 2007), p. 210.

${ }^{4}$ Zhonguo lishi 8.1, p. 97.

${ }^{42}$ Zhen Wang, "National Humiliation, History Education, and the Politics of Historical Memory: Patriotic Education Campaign in China", International Studies Quarterly 52.4(2008), pp. 783-806, pp. 790-793; see also Peter H. Gries, China's New Nationalism: Pride, Politics, and Diplomacy (University of California Press, 2004), p. 70.

${ }_{43}$ Caroline Rose, "Changing views of the Anti-Japanese War in Chinese high school history textbooks", in Paul Morris, Naoko Shimazu and Edward Vickers eds., Imagining Japan in Post-War East Asia: Identity Politics, Schooling and Popular Culture (Routledge, 2013), pp. 129-148, ff. 129-131.

${ }^{44}$ Denton, Kirk A. Exhibiting the Past: Historical Memory and the Politics of Museums in Postsocialist China (University of Hawaii Press, 2013), p. 284, FN 11.

${ }^{45}$ Shijie lishi 9. 2, p. 42.

${ }^{46}$ Paul Morris and Edward Vickers, "Unifying the Nation: The Changing Role of Sino-Japanese History in Hong Kong's History Textbook", in Paul Morris, Naoko Shimazu and Edward Vickers eds., Imagining Japan in Post-war East Asia: Identity Politics, Schooling and Popular Culture (Routledge 2013), p. 149.

${ }_{47}^{47}$ Edward Vickers, “Commemorating 'Comfort Women' beyond Korea: The Chinese Case”, in Mark R. Frost, Daniel Schumacher and Edwrad Vickers eds., Remembering Asia's World War Two (Routledge, 2019), p. 182.

${ }^{48}$ Zhonguo lishi 8.2, pp. 4-5.

${ }^{49}$ Zhonguo lishi 8.2, pp. 13-14.

${ }^{50}$ Herein I consider Bruce Cumings' influential, The Origins of the Korean War (Yuksa, 2002), to be a revisionist account not representative of the view of most Western specialists. For a more mainstream account see Charles K. Armstrong's Tyranny of the Weak: North Korea and the World, 1950-1992 (Cornell University Press, 2013).

${ }^{51}$ Zhonguo lishi 8.2, p. 7 .

${ }^{52}$ See Bertil Lintner, China's India War: Collision Course on the Roof of the World (Oxford University Press, 2018).

${ }^{53}$ See King C. Chen, China's War with Vietnam, 1979: Issues, Decisions, and Implications (Hoover Press, 1987).

${ }^{54}$ John Pomfret, The Beautiful Country and the Middle Kingdom (Picador, 2016), p. 5.

${ }^{55}$ Zhonguo lishi 8.2, p. 22.

${ }^{5}$ Zhonguo lishi 8.2, p. 27.

${ }^{57}$ Zhonguo lishi 8.2, p. 29. For Western scholarly approaches to the Great Leap Forward, see e.g. Kimberley Ens Manning and FelixWemheuer eds., Eating Bitterness: New Perspectives on China's Great Leap Forward and Famine (University of British Columbia Press, 2011).

${ }^{5}$ Zhonguo lishi 8.2, pp. 32-35. For mainstream Western scholarly coverage of the Cultural Revolution see e.g. Andrew G. Walder, China Under Mao: A Revolution Derailed (Harvard University Press, 2015). 
Journal of Global Faultlines, 2020

Vol. 7, No. 1, 114-125.

${ }^{59}$ Zhonguo lishi 8.2, pp. 39-40.

${ }^{60}$ Zhonguo lishi 8.2, p. 44. See also Marie-Claire Bergère, Shanghai: China's Gateway to Modernity (Stanford University Press, 2009).

${ }^{61}$ See Vickers and Yang, op. cit.

${ }^{62}$ Shijie lishi 9.2, p. 11.

${ }^{63}$ Shijie lishi 9.2, p. 27.

${ }^{64}$ See e.g. Pan Guang, "Shilun Nacui da tusha ji qi dui Youtai minzu de wenming de yingxiang", Shijie lishi 2(2000), pp. 12-22.

${ }^{65}$ David Shambaugh, China's Communist Party: Anthropy and Adaptation (University of California Press, 2008), Chapter 4.

${ }^{66}$ Shijie lishi 9.2, p. 60-63.

${ }^{67}$ Shijie lishi 9.2, p. 64-65.

${ }^{68}$ Shijie lishi 9.2, p. 91-92. 